\title{
USE OF NUCLEAR TECHNIQUE IN SAMPLES FOR AGRICULTURAL PURPOSES
}

\author{
KERLEY A. P. DE OLIVEIRA ${ }^{1}$, MARIA ÂNGELA B. C. MENEZES ${ }^{2}$, \\ VANUSA M. F. JACOMINO ${ }^{2}$, EDUARDO VON SPERLING ${ }^{1}$
}

\begin{abstract}
The concern related to environment is growing. Due to this, it is needed to determine chemical elements in a large range of concentration. The neutron activation technique (NAA) determines the elemental composition by the measurement of artificial radioactivity in a sample that was submitted to a neutron flux. NAA is a sensitive and accurate technique with low detection limits. An example of application of NAA was the measurement of concentrations of rare earth elements (REE) in waste samples of phosphogypsum (PG) and cerrado soil samples (clayey and sandy soils). Additionally, a soil reference material of the International Atomic Energy Agency (IAEA) was also analyzed. The REE concentration in PG samples was two times higher than those found in national fertilizers, (total of $4,000 \mathrm{mg} \mathrm{kg}^{-1}$ ), 154 times greater than the values found in the sandy soil $\left(26 \mathrm{mg} \mathrm{kg}^{-1}\right)$ and 14 times greater than the in clayey soil $\left(280 \mathrm{mg} \mathrm{kg}^{-1}\right)$. The experimental results for the reference material were inside the uncertainty of the certified values pointing out the accuracy of the method (95\%). The determination of La, Ce, Pr, Nd, Pm, Sm, Eu, $\mathrm{Tb}, \mathrm{Dy}, \mathrm{Ho}, \mathrm{Er}, \mathrm{Tm}, \mathrm{Yb}$ and $\mathrm{Lu}$ in the samples and reference material confirmed the versatility of the technique on REE determination in soil and phosphogypsum samples that are matrices for agricultural interest.
\end{abstract}

KEYWORDS: neutron activation analysis, multielemental analyses, phosphogypsum, rare earth elements.

\section{USO DE TÉCNICA NUCLEAR EM AMOSTRAS DE INTERESSE NA AGRICULTURA}

RESUMO: A preocupação crescente com o meio ambiente leva à necessidade de serem determinados elementos químicos em faixas de concentração cada vez mais largas. Entre as técnicas existentes, está a ativação neutrônica (AAN), que determina a composição química elementar por meio da medida da radioatividade artificial induzida ao se submeter uma amostra a um fluxo de nêutrons. A AAN possui alta sensibilidade, exatidão, precisão e natureza não destrutiva (dispensa tratamento químico prévio). Como exemplo de aplicação da técnica, elementos terras raras (ETR) foram determinados em amostras do resíduo fosfogesso (PG) e de solo do cerrado (argiloso e arenoso). Adicionalmente, um material de referência de solo da Agência Internacional de Energia Atômica foi analisado. A concentração de ETR no PG foi, em média, duas vezes maior que a encontrada na maioria dos fertilizantes nacionais (total de $4.000 \mathrm{mg} \mathrm{kg}^{-1}$ ), 154 vezes maior que no solo arenoso (26 mg kg-1) e 14 vezes maior que no solo argiloso $\left(280 \mathrm{mg} \mathrm{kg}^{-1}\right)$. Os resultados obtidos no material de referência confirmaram a exatidão do método com intervalo de confiança de 95\%. Foi comprovada a versatilidade da técnica ao serem determinados o $\mathrm{La}, \mathrm{Ce}, \mathrm{Pr}, \mathrm{Nd}, \mathrm{Pm}, \mathrm{Sm}$, $\mathrm{Eu}, \mathrm{Tb}, \mathrm{Dy}, \mathrm{Ho}, \mathrm{Er}, \mathrm{Tm}, \mathrm{Yb}$ e Lu em amostras de solo e fosfogesso de interesse na agricultura.

PALAVRAS-CHAVE: ativação neutrônica, análise multielementar, fosfogesso, elementos terras raras.

\footnotetext{
${ }^{1}$ Department of Sanitary and Environmental Engineering Federal University of Minas Gerais, Brazil, kerley@ufmg.br, kerleyfisica@yahoo.com.br.

${ }^{2}$ Brazilian Commission for Nuclear Energy Nuclear Technology Development Centre, Brazil.

Recebido pelo Conselho Editorial em: 8-9-2011

Aprovado pelo Conselho Editorial em: 9-8-2012
} 


\section{INTRODUCTION}

The neutron activation analysis is an analytical technique to determine the chemical composition and is based on irradiation of a sample with neutrons and subsequent measurement of the induced radioactivity. The most effective form of irradiation is using a nuclear reactor and is measured by gamma spectrometry. In the activation analysis, the specific energy of gamma radiation is used to determine the elements present in the sample, while the quantification is done by measuring the amount of gamma emission which are detected in a time interval (counts per second) (MENEZES et al., 2006). The NAA is used in determining the concentration of chemical elements in the percentage traits and can be applied to various matrices, including biomedical samples such as blood, tissue, hair and bone, environmental samples such as air and water filters and plants, geological samples such as rocks and minerals, in addition to a wide variety of industrial applications. The wide applicability of the technique is due to its most striking features, which are: ability to multi-element analysis, since it allows the identification and quantification of several elements simultaneously; allows the analysis of many elements, because about $70 \%$ of the natural chemical elements have adequate nuclear properties (half life, cross section and gamma energy) to be determined by neutron activation; has no destructive nature (analyzes samples with no previous chemical treatment prior to analysis); do not suffer interferences from chemical form in which the element is presented, because activation is a reaction that occurs in the nucleus of the atom and is independent of the chemical element considered; has high sensitivity ( $\mathrm{mg} \mathrm{g}^{-1}-\mathrm{ng} \mathrm{g}^{-1}$ ), accuracy, precision and detection limits in the range of part per trillion. These properties classify the NAA as a very versatile analytical technique, and, among other applications, it is recommended in the certification of reference materials besides being considered a primary technique (MENEZES et al., 2006).

As an example of applying the NAA technique, measures of concentration of rare earth elements (REE) in samples of waste from the phosphate industry (phosphogypsum) and cerrado soil samples (sandy and clayey) were performed, and a comparative results with reference material from the International Atomic Energy Agency (IAEA). For these measures, it was used the TRIGA research reactor (Training, Research, Isotope, General Atomics) MARK I IPR-RI from the Center of Nuclear Technology Development (CDTN/CNEN). This reactor is currently operating at a power of $100 \mathrm{~kW}$; using $20 \%$ enriched uranium as fuel and it is cooled by light water.

The residue studied in the experiment, phosphogypsum (PG), is the result of acid leaching of phosphate rock with concentrated sulfuric acid and water. As a product of this reaction there is the phosphoric acid and the residue, calcium sulphate dihydrate (phosphogypsum), which chemical and physical characteristics are similar to natural gypsum. Although the PG is mainly composed of calcium sulphate dihydrate, it can provide high levels of impurities from the phosphate rock matrix as metals $(\mathrm{Cd}, \mathrm{Zn})$, rare earths, metalloids such as As, fluorides and radionuclides. The PG generation rate is of approximately 4.8tons per ton of phosphoric acid (JACOMINO et al., 2009).

The PG has been used for decades as an agricultural input, mainly in the cerrado region, considered as the great agricultural frontier in Brazil, where its use is extremely important to ensuring the increased productivity of plantations. In this case, PG or "agricultural gypsum" is largely used as a source of calcium and sulfur such as subsurface conditioner and to correct soil saturated with sodium, potassium or aluminum (OLIVEIRA, 2008). However, the presence of toxic elements such as REE can accumulate in the soil and produce toxic effects in humans by bioaccumulation along the food chain. Studies conducted in areas rich in REE concluded that the constant exposure to these elements can cause damage to various body systems such as circulatory, immune, digestive, respiratory and nervous, but also can affect the intellectual development of children and strengthen the development of arteriosclerosis and pneumoconiosis (TURRA et al., 2011). Furthermore, the accumulation of REE in the soil may have a toxic effect on macro and micro fauna (LI et al., 2010). 
The objective of this study is to determine the concentration of REE by using the technique of NAA in PG residue used in agriculture as well as in soil samples from the cerrado, where PG has been used. Although there is not a specific legislation about the limits allowed for REE in samples of PG, and particularly in the soil, the results obtained in this study could serve as a support for building a database for possible future decision making about the impact of these elements on the environment.

\section{MATERIAL AND METHODS}

\section{Neutron Activation Analysis - Method $\boldsymbol{k}_{\boldsymbol{0}}$}

During irradiation of a sample, the interaction which occurs between the neutron and the nucleus of an element is a reaction of the type $(n, \gamma)$, in which the nuclide captures a neutron emitting gamma radiation. The likelihood of occurrence of this nuclear reaction depends on the characteristics of the target nuclide, as the cross section, the determined neutron energy, isotopic abundance, besides the half-life of the radionuclide formed (MENEZES et al., 2006; MUGHABGHAB, 2008).

In conventional methods of neutron activation analysis, samples and standards of the elements to be analyzed are simultaneously activated, and the concentrations of elements of interest determined by comparing their activities, characterizing methods related. In this study, we applied the $k_{0}$-standardization method (MENEZES et al., $2006 \mathrm{a} ; 2006 \mathrm{~b} ; 2011$ ) because there is no need to analyze patterns of elements of interest in parallel, in which the elemental concentrations are calculated using constants as $k_{0}$, as determined for each radionuclide, and available in the literature, reactor parameters and specific equations, where in parallel to the sample is irradiated only one neutron flux monitor or a standard for the calculation of specific activity. The first equation is the fundamental one of the method where $k_{0}$ is a natural constant of the isotopes being studied and can be calculated from its components. This method combines the simplicity of experimental methods for absolute neutron activation analysis with the accuracy of comparative methods. Equation 1 is applied to calculate the mass of the $\mathrm{i}$-th component in the sample, given the indexes $a$, referring to the sample, and $p$ to the pattern (MENEZES et al., 2006 a)

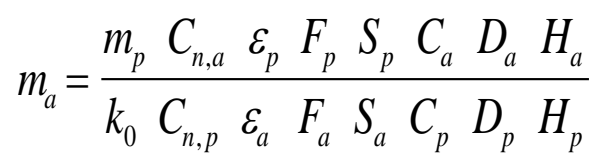

where,

$\mathrm{m}$ - mass of the element analyzed;

$\mathrm{C}_{\mathrm{n}}$ - net area of gamma peak of radionuclide of interest;

$\varepsilon$ - detector efficiency for gamma considered;

$\mathrm{F}-\left[\mathrm{f}+\mathrm{Q}_{0}(\alpha)\right]$, where $f$ is the ratio between thermal and epithermal neutron fluxes, which is defined from a determined energy and $\mathrm{Q}_{0}(\alpha)$ is the ratio between $\mathrm{I}_{0}(\alpha)$, resonance integral, and $\sigma_{\mathrm{o}}$, thermal neutrons cross section;

$\mathrm{S}$ - irradiation saturation factor in function of irradiation time;

C - radionuclide decay correction factor during counting;

D - radionuclide decay correction factor between radiation final and counting start, and

$\mathrm{H}$ - detector dead time during counting.

Regarding the $k_{0}$, it is defined by eq.(2):

$$
\mathrm{k}_{0}=\frac{\mathrm{M}_{\mathrm{p}} \theta_{\mathrm{a}} \mathrm{P}_{\gamma, \mathrm{a}} \sigma_{0, \mathrm{a}}}{\mathrm{M}_{\mathrm{a}} \theta_{\mathrm{p}} \mathrm{P}_{\gamma, \mathrm{p}} \sigma_{0, \mathrm{p}}}
$$


where,

$\mathrm{M}$ - element atomic weight;

$\theta$ - element isotopic abundance;

$P_{\gamma}$ - measured absolute abundance, and

$\sigma_{0}$ - thermal neutrons cross section.

The detection of gamma radiation emitted upon activation of the sample was performed by gamma spectrometry. The counting system is composed of an HPGe detector (High Pure Germanium) connected to a preamplifier, an analog-digital converter, a free of losses counter module, a multichannel analyzer (capable of storing information) and a microcomputer. After data acquisition and collection of spectra range, the energies of the gamma rays emitted, which are characteristic for each radionuclide, enabled the identification and quantification of elements. Importantly, the area under the peak range of the radionuclide is proportional to the concentration of the target element in the sample.

The computer programs used for the acquisition and analysis of the spectra were: Genie 2000 Basic Spectroscopy Software, brand CANBERRA: specific for the acquisition of gamma spectra of samples; HyperLab ${ }^{\circledR}$ 2005.2b: specific program for the deconvolution of spectra of gamma rays. It uses a database to store and manage effectively any information concerning spectra, and KAYZERO/SOLCOI ${ }^{\circledR}$ v.2.13rd: special program for calculating the elemental concentration of the sample by the $k_{0}$ method. It has corrections for phenomena of coincidence and calculation of elemental concentrations (and their associated uncertainties) by the $k_{0}$-standardization method. For such, it has several libraries with all nuclear information needed ( $k_{0}$ factors, corrections for decay branching, etc.) to 144 radioisotopes of analytical interest. It is important to mention that all the output results of the program include $3.5 \%$ systematic uncertainty and that the results are expressed in $\mathrm{mg} \mathrm{kg}^{-1}$.

The $k_{0}$-NAA method is an instrumental method; therefore, pattern/monitors are required to obtain the correction factors by the method used for elemental analysis of the samples. The monitors used are made of a certified alloy of Al-Au (1.0\%) IRMM-530R code, provided by the "Institute for Reference Materials and Measurements", and consist of a disc of $0.1 \mathrm{~mm}$ thick and $0.6 \mathrm{~cm}$ of diameter (MENEZES et al., 2006, 2011).

\section{Sample Collection and Preparation}

Thirty PG samples were collected in a company that produces phosphoric acid located in Uberaba, state of Minas Gerais - MG, Brazil. The collection points were defined in marked places and at regularly spaced intervals forming a mesh area of approximately $300 \mathrm{~m}^{2}$ on the surface of a local operational or active cell (battery in the PG has been regularly removed and stored for direct application in agriculture). The samples collected were packed in plastic bags, properly identified and sent to the laboratory.

Samples were collected from clayey Red Yellow Latosol of the city of Sete Lagoas - MG, and medium-texture Yellow Latosol of the city of Três Marias, both in the cerrado region of the state of Minas Gerais. Chemical or organic fertilizers were never applied in the select location. At each location it was collected approximately two tons of soil on a depth of $20 \mathrm{~cm}$, which corresponds to the tillable layer. The samples were sent to the Federal University of Viçosa (UFV), where they were scattered outsides to be dried naturally. All samples, after being dried, were sieved and the fraction chosen for analysis was the <200 mesh (MENEZES et al., 2006 b).

\section{Sample Analysis}

Aliquots of the PG and soil samples of approximately $200 \mathrm{mg}$ were weighted and transferred to their respective polyethylene tubes suitable for irradiation. These tubes are free of chemical impurities that may affect the results of the analysis. The samples (or irradiation tubes with samples) were placed in another tube of polyethylene stacked and alternated with monitors (Al-Au, 
$0.1 \%$ ). Thirty PG samples, four samples of virgin soil (two of sandy soil and two of clayey soil) and two IAEA/SOIL-7 reference soil were analyzed. The samples were irradiated in the reactor rotary rack TRIGA at $100 \mathrm{~kW}$, in the position $7, \mathrm{P}-7$, under a thermal neutron flux of $6.3510^{11}$ neutrons $\mathrm{cm}^{-2} \mathrm{~s}^{-1}$ for a time interval of 8 hours. In this P-7 position, $f$ and $\alpha$ parameters are $(22.3 \pm 2.0)$ and $(-0.0022 \pm 0.0002)$ respectively (MENEZES et al., 2006). (After each irradiation, it was expected an adequate time for the radionuclide to decay for shorter half-lives that might interfere with gamma spectrometry, which was performed on an HPGe detector (CANBERRA) with nominal 15\% efficiency, associated with the Genie 2000 spectra purchase program. The spectra obtained were analyzed using the HYPERLAB-PC and the REE concentrations were calculated by the program KAYZERO/SOLCOI ${ }^{\circledR}$ v.2.

\section{Results Quality Control}

Quality control of analytical results was made from analysis of reference material certified by the International Atomic Energy Agency, IAEA/SOIL-7 (IAEA, 1984), analyzed in duplicate. For the statistical evaluation of the results, two tests were used, which are the most frequently used (SHAKHASHIRO et al., 2006). The $z$-score test indicates that the uncertainty of the measurements is not considered in evaluating the performance of the method, while the $u$-score includes the uncertainties of the experimental measurements, as well as the certified values. Additional information regarding the performance of the analysis method used in this study, $k_{0}$, was provided by calculating the Expanded Uncertainty and expressed as "Relative Bias", $R B$, an estimate of the accuracy in percentage. The $R B$ shows that the experimental results are within the expanded confidence interval of $95 \%$.

In this study, the following equations were used in the calculations:

Experimental Expanded Uncertainty:

$$
U_{\text {expanded }}=\sqrt{\left(s^{2} / n\right)+u_{\text {método }}^{2}}
$$

where,

$\mathrm{s}$ - standard deviation of $\mathrm{n}$ replicates, and

$\mathrm{u}_{\text {method }}$ - total uncertainty of the $k_{0}$ method established in the CDTN/CNEN as 3,5\%, with a confidence factor of $k=1$.

"Relative Bias":

$$
\mathrm{RB}=\frac{\text { Value }_{\text {Experimental }}-\text { Value }_{\text {Certified }}}{\text { Value }_{\text {Certified }}} 100 \%
$$

z-score Test:

$$
\mathrm{z}_{\text {score }}=\frac{\text { Value }_{\text {Experimental }}-\text { Value }_{\text {Certified }}}{\mathrm{u}_{\text {Certified }}}
$$

where,

$\mathrm{u}_{\text {Certified }}$ - Confidence interval of $95 \%$ of the certified value.

The method performance is considered as satisfactory if $\mathrm{z}_{\text {score }} \leq 2$, questionable, if $2<\mathrm{z}_{\text {score }}<3$ and unsatisfactory if $\mathrm{z}_{\text {score }} \geq 3$.

u-score Test:

$$
\mathrm{u}_{\text {score }}=\frac{\mid \text { Value }_{\text {Experimental }}-\text { Value }_{\text {Certified }} \mid}{\sqrt{\mathrm{u}_{\text {Certified }}^{2}+\mathrm{u}_{\text {Experimental }}^{2}}}
$$


where,

$$
\mathrm{u}_{\text {Experimental }}=2 \mathrm{u}_{\text {expanded }}
$$

The method performance is considered as satisfactory if $u<1.96(\mathrm{P}=95 \%$ or $\pm 2 \sigma)$.

\section{RESULTS AND DISCUSSION}

Table 1 shows the results of concentration of each one of the REE analyzed in the PG and soil samples, as well as the certified and uncertified values and the experimental data for the IAEA/SOIL-7 reference material.

TABLE 1. REE concentrations in PG, soil samples and in the IAEA/SOIL-7 reference material.

\begin{tabular}{ccccccc}
\hline & \multicolumn{2}{c}{$\begin{array}{c}\text { PG } \\
\left(\mathrm{mg} \mathrm{kg}^{-1}, \text { dry weight }\right)\end{array}$} & $\begin{array}{c}\text { Soil } \\
\left(\mathrm{mg} \mathrm{kg}^{-1}, \text { dry mass }\right)\end{array}$ & $\begin{array}{c}\text { Reference Material } \\
\left(\mathrm{mg} \mathrm{kg}^{-1}, \text { dry weight }\right)\end{array}$ \\
\cline { 2 - 7 } REE & \multicolumn{2}{c}{$\begin{array}{c}\text { Concentration } \\
\text { range }\end{array}$} & $\begin{array}{c}\text { Sandy } \\
\mathrm{n}=2\end{array}$ & $\begin{array}{c}\text { Clayey } \\
\mathrm{n}=2\end{array}$ & $\begin{array}{c}\text { Experimental } \\
\text { Value }\end{array}$ & $\begin{array}{c}\text { Certified } \\
\text { Value }\end{array}$ \\
\hline $\mathrm{Ce}$ & $1,730 \pm 312$ & $1,503-2,304$ & $21 \pm 1$ & $148 \pm 7$ & $56 \pm 2$ & $61 \pm 6$ \\
$\mathrm{Dy}$ & $<8$ & - & $<3$ & $<3$ & $<8$ & $3.90 \pm 1.05$ \\
$\mathrm{Er}$ & $<50$ & - & $<5$ & $<5$ & $<5$ & $\mathrm{NR}$ \\
$\mathrm{Eu}$ & $29 \pm 6$ & $8-44$ & $<0.04$ & $2.0 \pm 0.8$ & $1.1 \pm 0.1$ & $1.0 \pm 0.2$ \\
$\mathrm{Ho}$ & $<4$ & - & $<0.4$ & $<0,4$ & $0.9 \pm 0.1$ & $1.1 \pm 0.1$ \\
$\mathrm{La}$ & $973 \pm 187$ & $715-1,059$ & $3.0 \pm 0.3$ & $62 \pm 3$ & $28 \pm 1$ & $28 \pm 1$ \\
$\mathrm{Lu}$ & $<60$ & - & $<160$ & $<160$ & $<160$ & $\mathrm{NR}$ \\
$\mathrm{Nd}$ & $791 \pm 229$ & $705-999$ & $<9$ & $41 \pm 6$ & $33 \pm 2$ & $30 \pm 6$ \\
$\mathrm{Pm}$ & $<5$ & - & $<5$ & $<5$ & $<5$ & $\mathrm{NR}$ \\
$\mathrm{Pr}$ & $233 \pm 16$ & $217-249$ & $<4$ & $13 \pm 3$ & $<4$ & $\mathrm{NR}$ \\
$\mathrm{Sm}$ & $85 \pm 21$ & $76-92$ & $0.39 \pm 0.02$ & $6.7 \pm 0.5$ & $4.7 \pm 0.5$ & $5.1 \pm 0.3$ \\
$\mathrm{~Tb}$ & $8 \pm 2$ & $7-11$ & $0.20 \pm 0.04$ & $1.2 \pm 0.3$ & $0.6 \pm 0.1$ & $0.6 \pm 0.2$ \\
$\mathrm{Tm}$ & $<2$ & - & $<1$ & $<1$ & $<0.6$ & $\mathrm{NR}$ \\
$\mathrm{Yb}$ & $5 \pm 2$ & $5-6$ & $1.5 \pm 0.1$ & $4.3 \pm 0.5$ & $2.4 \pm 0.1$ & $2.4 \pm 0.3$ \\
\hline $\mathrm{n}-\mathrm{number}$ of samples analyzed; NR - not reported. & & & & &
\end{tabular}

As can be seen, the REE that was most present in the PG samples was Ce $\left(1,730 \mathrm{mg} \mathrm{kg}^{-1}\right)$, followed by La $\left(973 \mathrm{mg} \mathrm{kg}^{-1}\right), \mathrm{Nd}\left(791 \mathrm{mg} \mathrm{kg}^{-1}\right)$ and $\operatorname{Pr}\left(233 \mathrm{mg} \mathrm{kg}^{-1}\right)$. The total concentration of REE in PG was about $4,000 \mathrm{mg} \mathrm{kg}^{-1}$ or $0.4 \%$. TURRA et al. (2011) found total values of REE concentration in samples of several inputs such as calcium nitrate (approximately $6 \mathrm{mg} \mathrm{kg}^{-1}$ ), magnesium sulfate (approximately $4 \mathrm{mg} \mathrm{kg}^{-1}$ ), magnesium nitrate (approximately $3 \mathrm{mg} \mathrm{kg}^{-1}$ ), monoammonium phosphate (MAP) (about $10 \mathrm{mg} \mathrm{kg}^{-1}$ ); in simple superphosphate (about $3,000 \mathrm{mg} \mathrm{kg}^{-1}$ ) and NPK fertilizers (ranging from $1,000 \mathrm{mg} \mathrm{kg}^{-1}$ to $2,000 \mathrm{mg} \mathrm{kg}^{-1}$ ).

Considering that the recommended application of PG in sandy soils is $0.99 \mathrm{t} \mathrm{ha}^{-1}$ and in clayey soils is $0.44 \mathrm{t} \mathrm{ha}^{-1}$ every four years (SOUZA et al., 1992), the amount of Ce applied would be around $1,712 \mathrm{~kg} \mathrm{ha}^{-1}$ (sandy soil) and $762 \mathrm{~kg} \mathrm{ha}^{-1}$ (clayey soil). The total amount of REE would be $3,969 \mathrm{~kg} \mathrm{ha}^{-1}$ and $1,760 \mathrm{~kg} \mathrm{ha}^{-1}$ for sandy and clayey soils, respectively.

Taking into account that the probability of groundwater contamination due to leaching of the REE as well as the mobility of REE in the soil are relatively low (HU et al., 2006; KABATA PENDIAS \& MUKHERIEE, 2007); the continuous application of PG can lead to accumulation of REE in soils used for agriculture, particularly those of the cerrado region. Therefore, in this case, the possible occurrence of deleterious effects to plants and the environment must be considered. 
The total concentration of REE on sandy soil was about $26 \mathrm{mg} \mathrm{kg}^{-1}$ (154 times smaller than in the PG), and $280 \mathrm{mg} \mathrm{kg}^{-1}$ (14 times lower than in the PG) in clayey soil. These results suggest that there may be a strong tendency to occur accumulation of such elements in the environment when using PG in the soil. Figure 1 illustrates a comparison between the concentrations of REE in PG and soil samples.

The element cerium was part of $81 \%$ and $53 \%$ of the total of REE in sandy and clayey soils, respectively. The results indicate that cerium is the most abundant REE in soil samples.

\section{Concentration of rare Earth $\left(\mathrm{mg} \mathrm{kg}^{-1}\right)$ in phosphogypsym and soil samples}

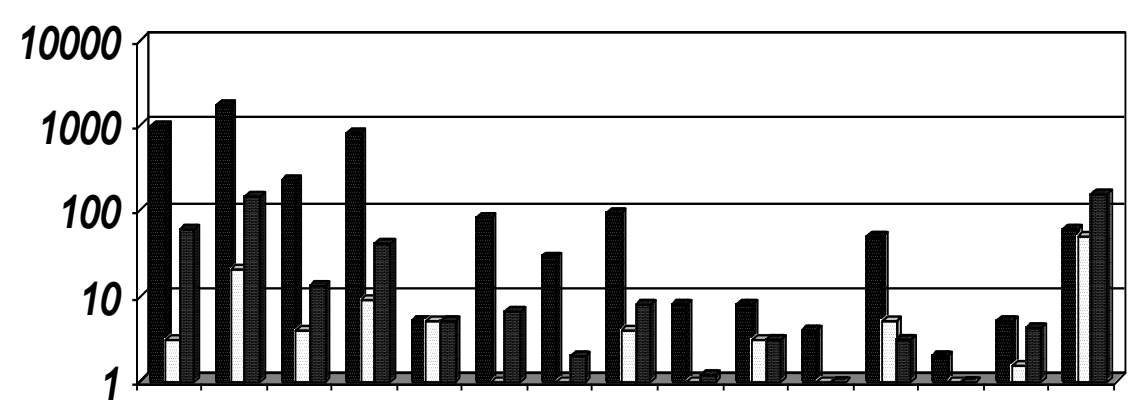

La Ce Pr Nd Pm Sm Eu Gd Tb Dy Ho Er Tm Yb Lu

Elements

\section{Dhosphogypsym $\square$ Sand Soil Clayey Soil}

FIGURE 1. Concentration of REE in the soil and PG samples.

The concentration of REE in the soil is strongly affected by their properties leading to large concentration variability. As expected (OLIVEIRA, 2008), in all cases, the clayey soil concentrated more elements than the sandy soil. It is worth remembering that the clay minerals are characterized by presenting a significant specific area, mainly resulting from its diminutive dimensions (of the order of micrometers to nanometers) and its elongated shape. The greater the surface area, the greater the capacity of retaining water, nutrients and other chemicals in the soil. It is also important to highlight that the highest concentration of negative charges in these clay minerals support the retention of cations. Added to this, other distinguishing characteristics of clayey soil that tends to have a high concentration of organic matter and high cation exchange capacity compared to sandy soil. These properties imply to clayey soil increased capacity of retain elements (OLIVEIRA, 2008; JACOMINO et al., 2009).

Table 2 shows the experimental results for the REE and the certified values, with a confidence interval of $95 \%$ for the IAEA/SOIL-7 reference material. The comparison between the experimental and certificate values were made by means of "Relative Bias", z-score and $u$-score tests. 
TABLE 2. Comparison between experimental values and values certified for IAEA/SOIL-7 reference material.

\begin{tabular}{ccccccc}
\hline $\mathrm{REE}$ & $\begin{array}{c}\text { Certified Values Experimental Values, } \mathrm{n}=2 \\
\left(\mathrm{mg} \mathrm{kg}^{-1}\right)\end{array}$ & $\begin{array}{c}\text { Confidence } \\
\text { Interval } \\
(\mathrm{mg} \mathrm{kg})\end{array}$ & $\begin{array}{c}R B \\
\%\end{array}$ & $z$-score & $u$-test \\
\hline $\mathrm{Ce}$ & $61 \pm 6$ & $56 \pm 2$ & -0.69 & -8.20 & 0.77 & 0.73 \\
$\mathrm{Eu}$ & $1.0 \pm 0.2$ & $1.1 \pm 0.1$ & -0.19 & +10.0 & 0.50 & 0.46 \\
$\mathrm{Ho}$ & $1.0 \pm 0.4$ & $0.9 \pm 0.1$ & -0.41 & -10.0 & 0.25 & 0.24 \\
$\mathrm{La}$ & $28 \pm 1$ & $28 \pm 1$ & -0.07 & 0.00 & 0.00 & 0.00 \\
$\mathrm{Nd}$ & $30 \pm 6$ & $33 \pm 2$ & -0.16 & +10.0 & 0.50 & 0.48 \\
$\mathrm{Sm}$ & $5.1 \pm 0.3$ & $4.5 \pm 0.5$ & -0.09 & -7.84 & 1.71 & 0.90 \\
$\mathrm{~Tb}$ & $0.6 \pm 0.2$ & $0.6 \pm 0.1$ & -0.50 & 0.00 & 0.00 & 0.00 \\
$\mathrm{Yb}$ & $2.4 \pm 0.1$ & $2.4 \pm 0.1$ & -0.10 & 0.00 & 0.00 & 0.00 \\
\hline
\end{tabular}

The $z$-score and $u$-scores tests show that the experimental results are within the confidence interval of $95 \%$. The $R B$ relative deviation is ranging from $-10.0 \%$, corresponding to the result of element concentration Ho, to +10.0 , corresponding to the results of elements Eu and $\mathrm{Nd}$, relative to negative values for the C.I., which means that they are within the expanded uncertainty (SHAKHASHIRO et al., 2006).

\section{CONCLUSIONS}

The result of the total concentration of PG found in REE $\left(4,000 \mathrm{mg} \mathrm{kg}^{-1}\right)$ confirms that it is rich in REE when compared to background mean values in environmental and agricultural inputs samples. The total concentration of REE in the sandy $\left(26 \mathrm{mg} \mathrm{kg}^{-1}\right)$ and clayey $\left(280 \mathrm{mg} \mathrm{kg}^{-1}\right)$ soils were well below those found in samples of PG. In all cases, the clayey soil concentrated more elements than sandy soil. Regarding the results of this study, we can conclude that depending on the concentration and frequency of the use of PG as an agricultural input, the high concentration of REE present in the PG may contribute to the accumulation of these elements in the soil, may cause deleterious effects not only to plants but also to the environment and to humans.

Quality control of analytical results was based on the analysis of certified reference material by the International Atomic Energy Agency, IAEA/SOIL-7. The experimental results presented values in accordance with the references quoted, which indicates the precision and accuracy of the analysis method NAA. The applied $z$-score and $u$-score tests as recommended by ISO/IEC 17025:2005 indicated that $k_{0}$ neutron activation analysis method was suitable for the analysis, confirming the good performance of the technique. Moreover, the results are within the expanded uncertainty. Besides this, the convenience of working with a mass sample of about a few dozens of milligrams, different matrices and of does not require chemical treatment prior to analysis, indicates the technique as an analytical tool suitable for determining REE in environmental samples and interest in agriculture.

\section{ACKNOWLEDGEMENTS}

The authors acknowledge CAPES (Coordination for the Improvement of Higher Education Personnel) for the financial support for developing the research presented in this study. The authors also thank Dr. Jaime Mello and MSc. David Faria, from the Federal University of Viçosa (UFV), for helping in collecting and processing the soil samples, and Fosfértil for donating the samples of PG.

\section{REFERENCES}

HU, Z., HANEKLAUS, S., SPAROVEK, G., SCHNUG, E. Rare earth elements in soils. Communications in Soil Science and Plant Analysis, New York, v.37, n.9, p.1381-1420, 2006. 
IAEA. INTERNATIONAL ATOMIC ENERGY AGENCY. Certified reference material IAEA/SOIL 7. Vienna: IAEA, (LAB/243), 1984. p.2.

JACOMINO, V.M.F.; OLIVEIRA, K.A.P.; TADDEI, M.H.T.; SIQUEIRA, M.C.; CARNEIRO, M.E.D.P.; NASCIMENTO, M.R.L.; SILVA, D.F.; MELLO, J.W.V. Radionuclides and heavy metal contents in phosphogypsum samples in comparison to cerrado soils. Revista Brasileira de Ciência do Solo, Campinas v.33, n.5, p.1481-1488. 2009.

KABATA-PENDIAS, A.; MUKHERJEE, A.B. Trace elements from soil to human. New York: Springer, 2007. $450 \mathrm{p}$.

LI, J.; HONG, M.; YIN, X.; LI, J. Effects of the accumulation of the rare earth elements on soil macrofauna community. Journal of Rare Earths. v.28, p.957-964. 2010.

MENEZES M.A.B.C.; JAĆIMOVIĆ R. Optimized $k_{0}$-Instrumental neutron activation method using the TRIGA MARK I IPR-R1 Reactor at CDTN/CNEN. Belo Horizonte: Nuclear Instruments \& Methods in Physics Research A, 2006, v.564, p.707-715.

MENEZES, M.A.B.C.; JAĆIMOVIĆ R. $k_{0}$-INAA quality assessment by analysis of soil reference material GBW07401 using the comparator and neutron flux monitor approaches. Applied Radiation and Isotopes, New York, v.69, p.1057-1063. 2011.

MENEZES, M.A.B.C.; PALMIERI, H.E.L.; LEONEL, L.V.; NALINI, J.R.H.A.; JAĆIMOVIĆ, R. Iron Quadrangle, Brazil: Elemental concentration determined by $k_{0}$-instrumental neutron activation analysis. Part I: Soil samples. J. Radioanal. Nucl. Chem., v.270, n.1, p.111-116. 2006 b.

MUGHABGHAB, S.F. Neutron cross sections from neutron resonance parameters and thermal cross sections. Disponível em: <http://ie.lbl.gov/ngdata/sig.htm> Acesso em: 23 out. 2008.

OLIVEIRA, K.A.P. Aplicação do fosfogesso na agricultura do cerrado e suas implicações radiológicas. 2008. 62 f. Dissertação (Mestrado em Ciência e Tecnologia das Radiações, Minerais e Materiais) - Centro de Desenvolvimento da Tecnologia Nuclear, Comissão Nacional de Energia Nuclear, Belo Horizonte, 2008.

SHAKHASHIRO, A.; AZEREDO, A.M.G.F.; SANSONE, U.; KIM, C.K.; KIS-BENEDEK, G.; TRINKL, A.; BENESCH, T.; SCHORN, R. IAEA, Report on the IAEA-CU-2006-05 proficiency test on determination of ${ }^{137} \mathrm{Cs}$ and ${ }^{210} \mathrm{~Pb}$ in spiked soil, IAEA / AL /167. 2006.

SOUZA, D.M.G.; REIN, T.A.; LOBATO, E.; RITCHEY, K.D. Sugestões para diagnose e recomendação de gesso em solos de cerrado. In: SEMINÁRIO SOBRE O USO DE GESSO NA AGRICULTURA, 2., 1992, Uberaba. Anais... Uberaba: Instituto Brasileiro do Fosfato, 1992. p.139-158.

TURRA, C.; FERNANDES, E.A.N.; BACCHI, M. A. Evaluation on rare earth elements of Brazilian agricultural supplies. Journal of Environmental Chemistry and Ecotoxicology, v.3, n.4, p.86-92, 2011. 